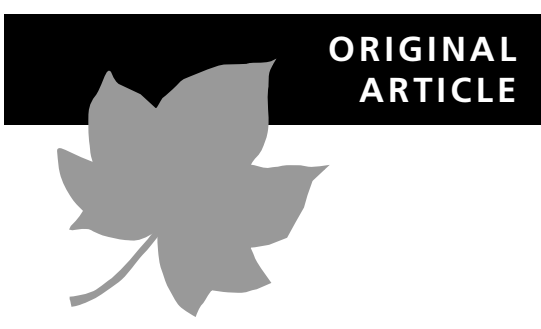

\section{Capybara (Hydrochoerus hydrochaeris) distribution in agroecosystems: a cross- scale habitat analysis}

Katia Maria P. M. de Barros Ferraz ${ }^{1}$, Silvio F. de Barros Ferraz², José Roberto Moreira $^{3}$, Hilton Thadeu Z. Couto ${ }^{1}$ and Luciano M. Verdade ${ }^{4}$
${ }^{1}$ Quantitative Methods Laboratory, Forest Science Department, 'Luiz de Queiroz' College of Agriculture (ESALQ), University of São Paulo (USP), Av. Pádua Dias 11, CP 09, Piracicaba, SP 13418-900, Brazil, ${ }^{2}$ Rural Engineering Department, 'Luiz de Queiroz' College of Agriculture (ESALQ), University of São Paulo (USP), Av. Pádua Dias 11, CP 09, Piracicaba, SP 13418-900, Brazil, ${ }^{3}$ EMBRAPA Genetic Resources and Biotechnology, Parque Estação Biológica - PqEB - Av. W5 Norte (final) - Brasília, DF 70770-900, Brazil, ${ }^{4}$ Animal Ecology Laboratory, Biological Science Department, 'Luiz de Queiroz' College of Agriculture (ESALQ), University of São Paulo (USP), Av. Pádua Dias 11, CP 09, Piracicaba, SP 13418-900, Brazil
${ }^{\star}$ Correspondence: Katia Maria P. M. de Barros Ferraz, Quantitative Methods Laboratory, Forest Science Department, 'Luiz de Queiroz' College of Agriculture (ESALQ), University of São Paulo (USP), Av. Pádua Dias 11, CP 09, Piracicaba, SP 13418-900, Brazil.

E-mail: kferraz@esalq.usp.br

\begin{abstract}
Aim The aim of this study was to understand the spatial distribution of capybara (Hydrochoerus hydrochaeris) according to habitat attributes, using a multiscale approach based on fine- and broad-scale variables in agroecosystems.
\end{abstract}

Location Piracicaba river basin, south-eastern Brazil $\left(22^{\circ} 00^{\prime}-23^{\circ} 30^{\prime}\right.$ S; $45^{\circ} 45^{\prime}-$ $\left.48^{\circ} 30^{\prime} \mathrm{W}\right)$.

Methods Potential habitats for capybara were selected in order to evaluate species presence/absence from October 2001 to December 2002. In each site, habitat attributes were sampled in the field (fine scale) and from GIS maps (broad scale) in terms of their presence or absence close to water. The variability of land cover between study sites was described by principal components analysis. Chi-square tests were calculated for capybara presence/absence and the presence of each habitat attribute. A linear discriminant function analysis was used to describe to what extent the species' presence could be explained by habitat attributes.

Results The species presence was predominantly related to flat open areas (slope ranging from $0 \%$ to $6 \%)\left(\chi^{2}=37.054\right.$, d.f. $\left.=4, P<0.001\right)$, covered by sugar cane or cultivated pasture $\left(\chi^{2}=84.814\right.$, d.f. $\left.=9, P<0.001\right)$. Terrain curvature, water meadows, aquatic vegetation, forest cover and open areas resulted in the best combination of variables, explaining $69.7 \%$ of capybara occurrence in the study sites in this river basin.

Main conclusions Capybaras are widespread in the Piracicaba river basin, except in elevated areas. The spatial distribution of capybara was associated with the main types of land cover in the river basin - sugar cane plantations or pasture - both key food sources for capybara. This probably explains the species' recent abundance in the region, since an intensive process of landscape alteration has taken place in this region owing to the expansion of agriculture in recent decades. These results may be useful in understanding the relationship between recent landscape modifications and the species' population expansion in agroecosystems.

\section{Keywords}

Agroecosystems, Brazil, capybara, Hydrochoerus hydrochaeris, scale, spatial distribution.

\section{INTRODUCTION}

South-eastern Brazil has been undergoing an intensive process of landscape alteration owing to the expansion of agriculture and pasture in recent decades (Igreja et al., 2001; Vicente et al.,
2001; São Paulo, 2005). In São Paulo State, south-eastern Brazil, the conversion of natural habitats into agriculture and pasture (change from C3 to C4 vegetation) between 1962 and 1992 resulted in a loss of 4.1 million ha $(57.13 \%)$ of original vegetation (Kronka, 1994). According to the last forest 
inventory of São Paulo State (Kronka et al., 2003) there has, however, recently been a small increase of about $3.8 \%$ in native forest cover.

About $70 \%$ of the Piracicaba river basin, one of the most anthropogenic regions in south-eastern Brazil (São Paulo (Estado), 1994, 2001; Krusche et al., 2003), is covered mainly by sugar cane and pasture, and only $10 \%$ is covered by original forest (Ballester, 2001). In recent years, capybaras (Hydrochoerus hydrochaeris), the largest rodent widely distributed in South America, have been considered a potential pest in the region owing to the species' high population densities (Verdade \& Ferraz, 2006), which are associated with crop damage (Ferraz et al., 2003) and risk of zoonotic diseases (Pereira \& Labruna, 1998; Labruna et al., 2001, 2004).

The increase in habitat carrying capacity, which results from rising agricultural production, and the decline in natural predators in south-eastern Brazil are possibly the two main factors that are contributing to the dynamic process of capybara population increase in human-altered landscape habitats. Moreover, the ban on hunting by Brazilian Federal Law No. 5197 of 1967 (Brasil, 1967) and the reproductive characteristic of the species (Ojasti, 1973) may also have contributed to its habitat expansion and population increase in the region.

Capybaras are semi-aquatic grazers that dwell in many different types of habitats, from riparian forest to seasonally flooded savannas (Ojasti, 1973, 1991; Moreira \& Macdonald, 1997). These habitats are generally composed of grasslands used for feeding, a bush or forest used for resting and parturition, and a water body used mainly for mating, body cooling and predator avoidance (Ojasti, 1973; de Azcárate, 1980; Macdonald, 1981; Alho et al., 1989; Moreira \& Macdonald, 1997). The utilization of the habitat components varies seasonally depending on the availability of water and food (Herrera \& Macdonald, 1989). The home range location and shape follow the drainage configuration, emphasizing the importance of water for capybaras (Herrera \& Macdonald, 1989).

Despite their wide distribution in South America, capybaras have not been intensively studied in anthropogenic habitats such as that of south-eastern Brazil, where they have been considered to be a potential pest for agriculture. In this study, we aim to understand the spatial distribution of capybara according to habitat attributes in agroecosystems in the Piracicaba river basin using a multiscale approach (fine and broad scale). The results may be useful in understanding the relationship between landscape modifications and the species' population expansion and increase in the region.

\section{METHODS}

\section{Study sites description}

The study sites were located in the Piracicaba river basin, which is a developed meso-scale basin in south-eastern Brazil $\left(22^{\circ} 00^{\prime}-\right.$ $23^{\circ} 30^{\prime} \mathrm{S} ; 45^{\circ} 45-48^{\circ} 30^{\prime} \mathrm{W}$ ) (Fig. 1). The basin is c. $12,400 \mathrm{~km}^{2}$, corresponding to $4.7 \%$ of the State of São Paulo, with about 3 million inhabitants. It encompasses 61 municipalities, some of them with reports of crop damage by capybara and cases of Brazilian Spotted Fever (Ferraz et al., 2003; Labruna et al., 2004).

The Piracicaba river basin has a highly dense drainage system, with about $7854 \mathrm{~km}$ of watercourses. The original vegetation was predominantly semideciduous subtropical forest with small areas of savannas (Instituto Geográfico e Cartográfico do Estado de São Paulo (IGC), 1980). Since 1850,

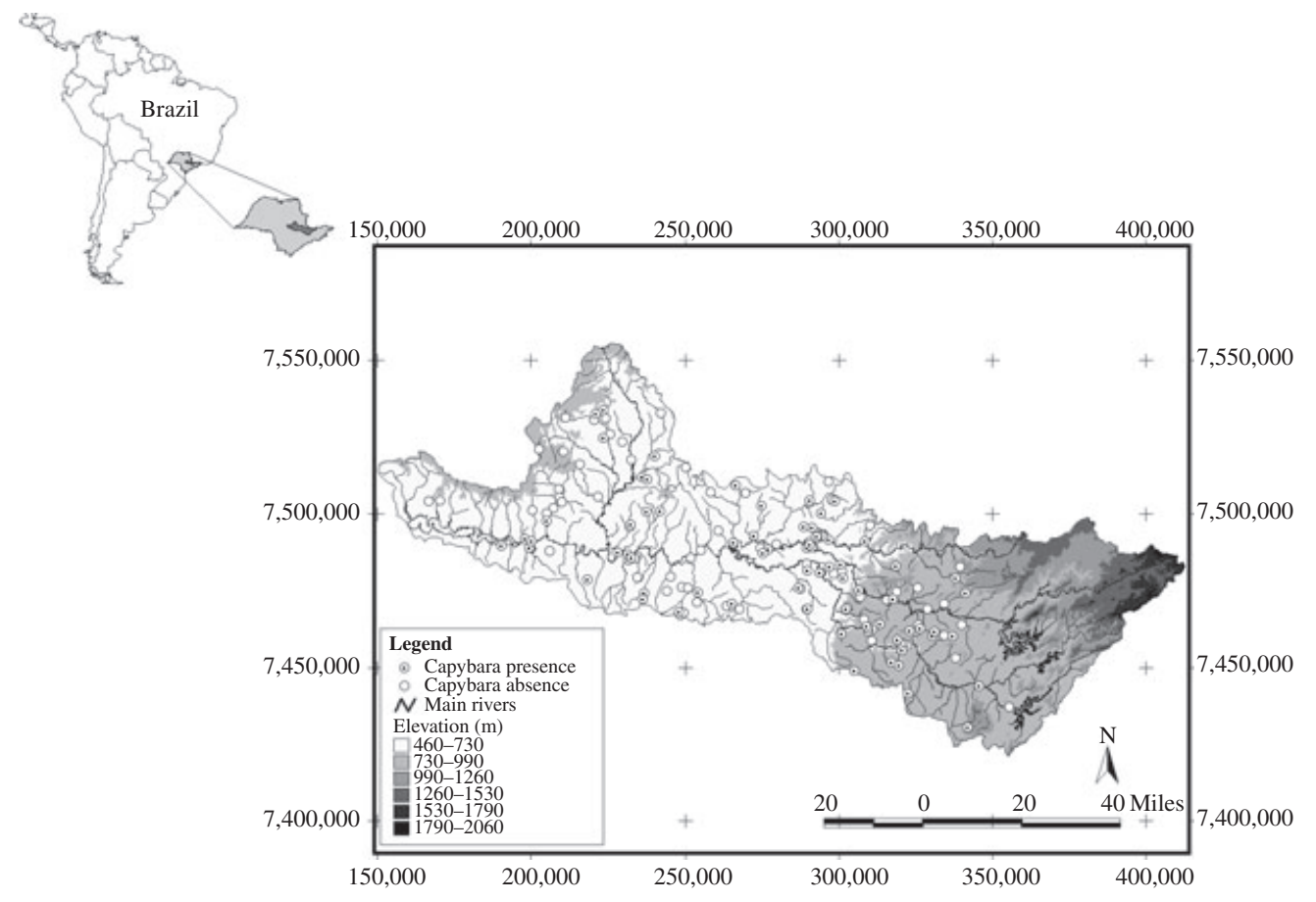

Figure 1 Location of study sites in the Piracicaba river basin, south-eastern Brazil. 
Table 1 Habitat attributes of the study sites sampled in the field and obtained from GIS maps, in the Piracicaba river basin, south-eastern Brazil

\begin{tabular}{|c|c|}
\hline Habitat attribute & Description \\
\hline \multicolumn{2}{|c|}{ Variables collected in the field } \\
\hline Wetland & Flat areas subjected to inundation in the wet season with great variation in the water volume \\
\hline Water meadow & Water body adjacent to a river with great variation in the water volume \\
\hline Aquatic vegetation & $\begin{array}{l}\text { Typical aquatic vegetation in the water body, for example Hedychium coronarium (butterfly lily) and Typha } \\
\text { dominguensis (cattail) }\end{array}$ \\
\hline Wetland vegetation & $\begin{array}{l}\text { Typical wetland vegetation associated with the water body, generally linking different water bodies or } \\
\text { following the watercourse }\end{array}$ \\
\hline Forest cover & Forest or bush vegetation near the water body \\
\hline Open area & Natural or cultivated pasture, and grasslands near water body \\
\hline Agriculture & Annual or perennial agricultural fields near water body \\
\hline Human presence & Any kind of human settlements or roads near water body, but not necessarily urban areas (cities) \\
\hline \multicolumn{2}{|c|}{ Variables obtained from GIS maps ${ }^{\star}$} \\
\hline Land cover & $\begin{array}{l}\text { Categorical variable according to the land-cover classes: water (1), urban (2), sugar cane (3), pasture (4), } \\
\text { silviculture (5), forest (6), annual crop (7), perennial crop (8), bare soil (9), others (10) }\end{array}$ \\
\hline Soil & $\begin{array}{l}\text { Categorical variable according to the soil classes: oxissol (1), alfissol (2), ultissol (3), inceptissol (4), entissol } \\
\text { (5), hydromorphic (6), cambissol (7) }\end{array}$ \\
\hline Slope & Terrain slope $(\%)$ \\
\hline Distance from a river & Gradient distance in metres from the closest main river \\
\hline Elevation & Elevation in metres \\
\hline Terrain curvature & Terrain curvature wetness $(-1,0$ or +1$)$ \\
\hline
\end{tabular}

Soil wetness calculated by the Topographic Wetness Index.

${ }^{*}$ GIS maps were provided by the Piracena Project (http://www.cena.usp.br/piracena/) and by Instituto Florestal de São Paulo.

the original forest has been intensively replaced by pasture and sugar cane (Dean, 1977; Ballester, 2001; Krusche et al., 2003). This basin can be considered as an agroecosystem (about $43 \%$ pasture and $31 \%$ sugar cane), with only $10 \%$ of the original forest remaining (Martinelli et al., 1999; Lara et al., 2001; Krusche et al., 2003). Pasture, silviculture and forest predominate in upstream regions, and sugar cane plantations are more common in downstream ones.

\section{Sampling}

The potential habitats for capybara occurrence in the area were chosen for sampling in the field initially by videography (Sidle \& Ziewitz, 1990; Couto et al., 2000), and later by Landsat5 TM interpretation. The videography was carried out using a video camera (Panasonic S-VHS AG-750P $5.6 \mathrm{~mm}$ ) and a video recorder (JVC S-VHS HR-S5400U) filming from a CESSNA aeroplane. A GPS Garmin III Plus was linked to a Horita GPT50 (a video titler that adds real-time GPS data to video for recording or viewing) and to a video recorder. This allowed the geographic coordinates to be saved in the image for further geo-referencing and easy location in the field. Besides being low cost, videography allows the location of small habitat patches not detectable in the coarser satellite images. The minimum criterion for site selection was the presence of a water body (pond, wetlands, reservoir or lagoon), essential for capybara survival (Ojasti, 1973; Herrera \& Macdonald, 1989). The land cover around the water body was not considered in the study-site selection in order to allow sampled habitat types to vary greatly. One hundred and fifty-five study sites were selected to be sampled in the field. GIS maps and satellite images were used to locate the study sites precisely in the field with an Ipaq H3850 connected to a GPS Garmin Etrex.

Potential habitats for capybara were sampled in the field (Fig. 1) from October 2001 to December 2002. Each study site was visited once by a single observer. The sampling effort employed and the observer were the same for all localities. Since direct observation of the species is difficult in anthropogenic habitats (capybaras were observed in only $8.38 \%$ of the study sites), capybara presence was inferred from signals left by individuals. During the sampling, the observer walked around the water body and in the open areas within the study site looking for individuals and for scats and tracks, as capybara signs are very conspicuous and easily found. Capybaras were considered present in the area when any scat, track, call or individual was found. Because the main object of this study was to infer the spatial distribution of capybaras by their presence or absence, no effort was made to evaluate their density in any of these 155 sites.

Besides capybara presence/absence, habitat attributes were sampled in the field and from GIS maps (pixel of $100 \mathrm{~m}$ resolution) for their presence or absence close to water. These habitat attributes are listed and described in Table 1. It is important to note that two different scales have been considered in the data collection and analysis: fine scale for samples collected in the field, and broad scale for samples obtained from GIS maps. These different scales could result in different values (for example for land cover) owing to the resolution and/or classification of the maps. 


\section{Data analysis}

The variability of land cover (proportion of land cover in a buffer zone of $500 \mathrm{~m}^{1}$ from the water borders, i.e., in an area of $78 \mathrm{ha}^{2}$ ) amongst study sites was described by principal component analysis. Chi-square tests were calculated for dependent (capybara presence/absence) and independent (presence/absence of each habitat attribute listed in Table 1) variables. The expected values were calculated by multiplying the total observed presence or absence of the species (for that habitat attribute) by the total presence or absence of each habitat attribute, and dividing by the total observations (for that habitat attribute). Four types of water body were considered in these tests: (1) small pond (small artificial water body formed by damming and draining), (2) reservoir, (3) wetland, and (4) lagoon (natural lake). Study sites were classified into four groups of habitat: (1) small ponds with no forest cover, (2) small ponds with forest cover, (3) wetland and lagoon (these two were grouped together because of the small sample size, $n=5$ and $n=3$, respectively), and (4) reservoirs.

A linear discriminant function (LDF) analysis (McGarigal et al., 2000) was used to describe how well the presence of the species could be explained by the independent variables (habitat attributes listed in Table 1). As some habitat attributes verified in the field were not exactly the same as on the GIS maps (as explained above), variables were analysed in the discriminant models in different ways: (1) LDF Var_GIS: variables sampled just from GIS maps; (2) LDF Var_Field: variables sampled just in the field; (3) LDF Var_GIS + Var_Field: variables sampled from GIS and in the field; and (4) LDF with each combination of variables.

The relationship between the species presence and habitat attributes on a broad scale was clarified with a biplot graph of a principal components analysis (Gabriel, 1971), considering the proportion of the main land-cover classes, distance from a river, wetness and slope in 78 ha of each study site (i.e., in a circle of radius $500 \mathrm{~m}$ ). Other variables were discarded from the analysis because of their low variance in the samples.

\section{RESULTS}

Capybara distribution was directly associated with the main types of land cover in the river basin, namely sugar cane and pasture (Fig. 2). Most of the variability (85\%) of land cover in the study sites was explained by the first component. Pasture and sugar cane, the two variables with the highest correlation with the first component, were inversely correlated with each other (Table 2).

As the study sites were visited during the day, the incidence of direct observation of capybara was very low (about $8.38 \%$ ). However, capybara are widespread in the river basin, except in the elevated areas. Capybara presence was confirmed in about

${ }^{1}$ Approximate distance that capybaras can be found from water in anthropogenic habitats.

${ }^{2}$ Area of a circle of radius $500 \mathrm{~m}$.

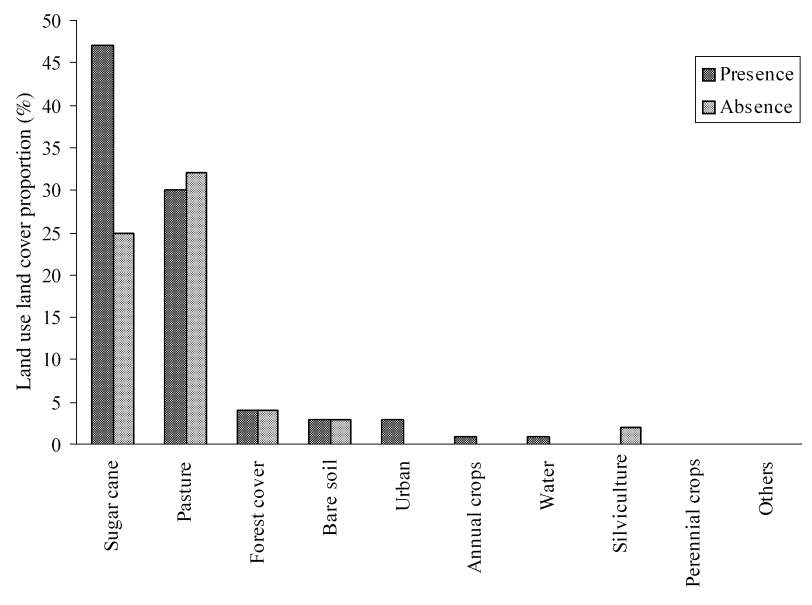

Figure 2 Distribution of presence and absence of capybara (Hydrochoerus hydrochaeris) in relation to land cover in the Piracicaba river basin, south-eastern Brazil.

Table 2 Principal components analysis of the land cover of the study sites in a buffer zone of $500 \mathrm{~m}$ from the water borders, in the Piracicaba river basin, south-eastern Brazil

\begin{tabular}{|c|c|c|c|}
\hline & \multicolumn{3}{|c|}{ Component } \\
\hline & I & II & III \\
\hline Proportion (\%) & 85.0 & 8.9 & 4.2 \\
\hline Cumulative (\%) & 85.0 & 93.8 & 98.1 \\
\hline \multicolumn{4}{|c|}{ Variables (correlation) } \\
\hline Urban & -0.000 & -0.724 & -0.456 \\
\hline Sugar cane & -0.735 & 0.444 & -0.152 \\
\hline Pasture & 0.677 & 0.492 & -0.204 \\
\hline Silviculture & 0.024 & -0.007 & -0.012 \\
\hline Forest & 0.031 & -0.190 & 0.853 \\
\hline Annual crop & 0.009 & -0.000 & -0.013 \\
\hline Perennial crop & -0.004 & -0.001 & -0.000 \\
\hline Bare soil & 0.009 & 0.004 & -0.007 \\
\hline
\end{tabular}

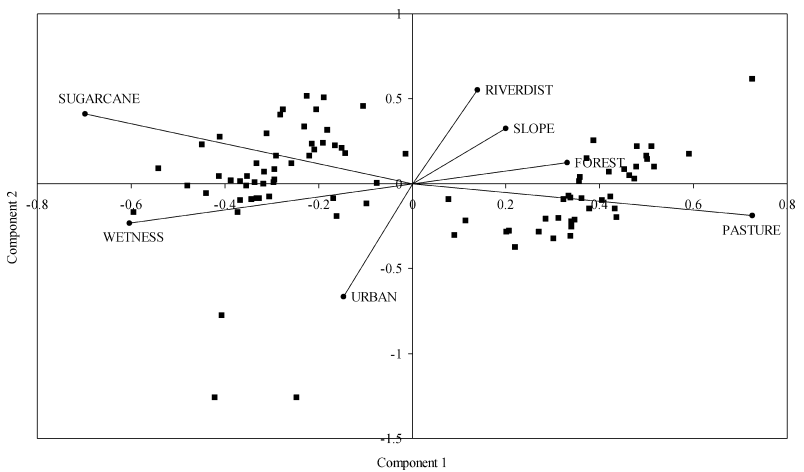

Figure 3 Biplot graph of principal components explaining the presence of capybara (Hydrochoerus hydrochaeris) in relation to land-cover proportion (sugar cane, pasture, forest, urban), slope, wetness, and distance from a river (riverdist). 
$57.42 \%$ of the study sites. The species presence was predominantly related to flat open areas (slope ranging from $0 \%$ to $6 \%)\left(\chi^{2}=37.054\right.$, d.f. $\left.=4, P<0.001\right)$, covered by sugar cane and cultivated pasture $\left(\chi^{2}=84.814\right.$, d.f. $\left.=9, P<0.001\right)$.

The biplot graph of principal components explaining capybara presence (Fig. 3) revealed that the species is found mainly in landscapes dominated by pasture or sugar cane. The proportions of these two habitat attributes are inversely correlated, since they are not commonly found in the same site. The high correlation between sugar cane and pasture shows that land-cover type seems to be the most important factor for the presence of animals in the river basin.

Sugar cane areas are related to topographic wetness, explained by the fact that sugar cane is usually cultivated in the lowlands of the Piracicaba river basin. Pasture areas are located on the steeper slopes with the presence of small and scarce forest patches. The second principal component is more closely related to distance from a river and the presence of urban areas. Apart from the variance in the presence data set, it seems that distance from a river and the presence of urban areas do not greatly influence capybara occurrence, since no pattern was observed in presence points.

The type of water body did not influence the presence/ absence of capybara $\left(\chi^{2}=3.65\right.$, d.f. $\left.=3, P=0.302\right)$. Nevertheless, the type of habitat significantly influenced the species

Table 3 Chi-square test between the presence/absence of habitat attributes and of capybaras (Hydrochoerus hydrochaeris) in the study sites, in the Piracicaba river basin, south-eastern Brazil

\begin{tabular}{lrl}
\hline Habitat attribute & $\chi^{2}$ & $P$ \\
\hline Forest cover & 8.568 & 0.003 \\
Wetland & 8.171 & 0.004 \\
Water meadow & 9.428 & 0.002 \\
Aquatic vegetation & 0.055 & 0.815 \\
Wetland vegetation & 11.440 & 0.001 \\
Open area & 2.229 & 0.135 \\
Agriculture & 0.171 & 0.680 \\
Human presence & 4.105 & 0.043 \\
\hline
\end{tabular}

Table 4 Percentage of correctness in the estimation of the presence of capybara (Hydrochoerus hydrochaeris) by discriminant analysis (LDF - linear discriminant function), with habitat attributes sampled in the study sites from GIS maps (Var_GIS) and in the field (Var_Field)

\begin{tabular}{ll}
\hline Predictors & $\begin{array}{l}\text { Percentage of correctness } \\
\text { of capybara presence }\end{array}$ \\
\hline LDF Var_GIS & 61.9 \\
LDF Var_Field & 62.6 \\
LDF Var_GIS + Var_Field & 67.1 \\
LDF Var_GIS (terrain curvature) + & 69.7 \\
Var_Field (water meadow + & \\
aquatic vegetation + forest cover + \\
open areas)
\end{tabular}

presence/absence $\left(\chi^{2}=11.55\right.$, d.f. $\left.=3, P=0.009\right)$. The habitat attributes named wetland, water meadow, forest cover, and wetland vegetation also significantly influenced the species presence/absence (Table 3). The other variables studied did not show any significant effect on the species presence/absence.

The correctness of the estimate of capybara presence and absence as a function of the habitat attributes (sampled in the field and from GIS maps) was quite similar. The model considering all variables improved the results by only $8.4 \%$. Terrain curvature, water meadows, aquatic vegetation, forest cover and open areas resulted in the best combination of variables, explaining $69.7 \%$ of capybara occurrence in the study sites in this river basin (Table 4).

\section{DISCUSSION}

Capybara habitats in the Piracicaba river basin are characterized by the presence of a water body surrounded by flat open areas associated with agricultural fields and small patches of forest cover, and with a strong human presence. As emphasized by this study, capybara habitat, unlike that previously described for the species in other regions (Herrera \& Macdonald, 1989; González Jiménez, 1995), is described as very anthropogenic with C4 plants (sugar cane or pasture) predominating, as suggested by the first component in the principal components analysis. The landscape matrix of this basin is composed of pasture in the upstream regions and sugar cane downstream.

The low frequency of direct observation of capybara in the study sites is possibly a result of the time of data collection and the behavioural changes of the species: it is well known that the capybara becomes typically nocturnal and secretive in anthropogenic areas or in areas under high hunting pressure (Moreira \& Macdonald, 1997), as happens with other species (Verdade, 2006). Nevertheless, this pattern did not affect detection of the species presence/absence since signals were easy to find and were an effective tool in open areas and near water in all study sites.

On the fine scale (variables collected in the field), the individual attributes of habitat that affected capybara presence were the presence of forest cover, wetland, wetland vegetation and water meadows. The presence of forest cover probably affects capybara presence because it provides protection from predation/hunting, and hunting pressure is presumably high in the region. The species is very much present in wetland and wetland vegetation, possibly because these habitats are good food sources for capybara, while wetland vegetation could also serve as a hiding place. Seasonally flooded water meadows could be important for the species because this attribute is possibly related to the dispersion of the species - empirical observations in these anthropogenic habitats have suggested that capybara use watercourses as corridors for seasonal movements and habitat colonization. It was also observed that capybaras prefer to access food areas by water, rather than by land. All these habitat requirements for capybaras are strictly associated with their ecology as a large semi-aquatic territorial herbivore. 
The relationship between capybara presence and habitat attributes emphasizes the importance of the type of land cover as a food source for the species. Capybara distribution was related to habitats with a high proportion of either pasture or sugar cane, as these two types of land cover rarely occur in the same region in this river basin. For capybara, sugar cane areas represent food and also cover (at least during part of the year, and especially close to water bodies with no floating vegetation). On the other hand, cultivated pasture alone (with no forest patches) represents only food for capybara. The association of pasture with small and scarce forest patches could provide cover for the species. This is also the case for water bodies with no floating vegetation. This may explain why capybara can occur both in habitats with sugar cane and in habitats with pasture and forest. Quintana \& Rabinovich (1993) noticed that capybara presented higher densities in lagoons with rooted and floating vegetation than in lagoons with no vegetation, since the former environment offers a safe refuge for the species. It is important to note that, if these open habitats with pasture and small forest patches had all their riparian forest intact, as demanded by the Forest Law in Brazil (CONAMA, 2002), capybara presence in these areas would probably be rarer than it currently is. Small forest patches in habitats predominated by sugar cane or pasture are good for cover, but larger forest patches in these habitat types may decrease the carrying capacity for the species as they would replace the food source surrounding water (pasture or sugar cane). Aldana-Dominguéz et al. (2002) also noted that habitats with C4 plants had higher densities of capybara than others such as riparian forests.

The fact that sugar cane was not associated with forest cover in this study raises the following question. Once sugar cane is harvested for the mills, where do capybaras go? We still know very little about the use and shape of the capybara home range in anthropogenic areas, but it apparently is a long stretch along a river basin encompassing agricultural areas for food and patches of riparian forest or water bodies with floating vegetation for cover (Moreira et al., 2001; Verdade \& Ferraz, 2006). After the harvest, capybaras probably disperse to another water body within their home range with enough resources (food and cover) to support them until the next crop. Apparently, capybaras' use of human-altered landscapes, such as this one, is much more dynamic than that in pristine habitats. Capybaras must be very adaptable to the frequent modifications of land use that happen in agricultural landscapes (Ferraz et al., 2003; Verdade \& Ferraz, 2006). Our sampling protocol provided information about the fine-scale spatial distribution of capybaras, but not about the temporal distribution.

Urban areas (on a broad scale) and human presence (on a fine scale) did not seem to be limiting factors for capybara occurrence. This perhaps surprising result could be related to species protection (low hunting pressure), such as found in recreational and residential areas. In rural areas, the low presence of the species could be the result of high hunting pressure. According to Quintana \& Rabinovich (1993), hunting pressure seems to be an important factor in determining capybara density in different habitat types. These authors found that protected sites had higher capybara densities than those where poaching occurred, even if both provided good habitat quality.

A cross-scale analysis revealed that capybara presence was explained mainly by a combination of field variables and GIS variables. The percentage of correctness was not high, however, a result that could be related to the fact that capybara can inhabit a great variety of habitats (Moreira \& Macdonald, 1997). Variables sampled in the field and from GIS maps showed similar results when explaining capybara presence. The relevance of the data collected in the field should be carefully considered in future studies. Variables such as patch shape and size should possibly be included in order to improve model accuracy. All the best variables selected in the best linear discriminant model reflect the importance of resources such as food, water, and shelter for the species.

In this study, the spatial distribution of capybara was related mainly to food source (C4 plants such as sugar cane and grass). Capybaras have a strong capacity to adapt to a wide variety of anthropogenic habitats. Besides being considered selective grazers in flooded savannas when food is abundant (González Jiménez, 1978; Herrera \& Macdonald, 1989; Barreto \& Herrera, 1998), capybaras in agroecosystems seem to be more opportunistic in relation to the novel resources available, since landscape changes in agroecosystems are more dynamic than those in non-agricultural landscapes. Investigations into the feeding habits of capybaras in agroecosystems should be carried out along the lines of those studies that have been conducted in areas subjected to flooding (Quintana et al., 1994, 1998; Barreto \& Herrera, 1998).

The formation of potential habitats for capybara by agriculture and pasture expansion could have favoured the rapid species expansion and colonization of these new habitats. As stressed by Eisenberg et al. (1979), capybara can be a good example of an $r$-strategist species, prone to expand under optimum conditions. The high availability of food resources, such as sugar cane, corn or grass, especially near watercourses, increases the habitat carrying capacity for capybara, resulting in population growth (Moreira, 2004), similar to what happens for ungulates (McCullough, 1997).

As a consequence of capybara abundance, conflicts involving this species and humans have been reported frequently in the region, mainly because of crop damage (Ferraz et al., 2003) and, more recently, because of the spread of Brazilian Spotted Fever (Labruna et al., 2001, 2004). Elsewhere in Brazil, urban conflicts such as garden damage (Moreira et al., 2001) have also been reported. Management actions are urged in areas with these conflicts. Programs for species control should consider habitat management at first, recovering riparian forests and so reducing the habitat carrying capacity for capybaras. Harvesting programs similar to those practised in Venezuela since the 1960s (Ojasti, 1973, 1991) could also be carried out, as the species can produce as much as $630 \mathrm{~kg} \mathrm{~km}^{-2} \mathrm{yr}^{-1}$ in high-quality habitats in the agroecosystems of south-eastern Brazil (Verdade \& Ferraz, 2006). 


\section{ACKNOWLEDGEMENTS}

This study was supported by Fundação de Amparo à Pesquisa do Estado de São Paulo - FAPESP (00/00180-9 and 00/00602$0)$ and partially supported by Coordenação de Aperfeiçoamento Pessoal de Nível Superior - CAPES. We are grateful to Dr Gilberto Garcia, Dr Maria Victoria R. Ballester, and Dr Peter G. Crawshaw Jr for their valuable contributions throughout this study, to Gustavo R. M. Pinto for his strong support in the fieldwork, and to Susie Casement and Dr Concepta McManus for English revision. We thank Projeto Piracena and Instituto Florestal de São Paulo for providing the digital maps. Finally, we thank IDEAWILD for the donation of the equipment for this project.

\section{REFERENCES}

Aldana-Dominguéz, J., Forero-M.,J., Betancur, J. \& Cavelier, J. (2002) Dinâmica y estructura de la población de chigüiros (Hydrochaeris hydrochaeris: Rodentia, Hydrochaeridae) de Caño Limón, Arauca, Colombia. Caldasia, 24, 445-458.

Alho, C.J.R., Campos, Z.M. \& Gonçalves, H.C. (1989) Ecology, social behavior and management of the capybara in the Pantanal of Brazil. Advances in Neotropical mammalogy (ed. by K.H. Redford and J.F. Eisenberg), pp. 163-194. Sandhill Crane Press, Gainesville.

de Azcárate, T. (1980) Sociobiologia y manejo del capibara (Hydrochoerus hydrochaeris). Donana Acta Vertebrata, 7, 1228.

Ballester, M.V.R. (2001) Características da paisagem e qualidade daágua na bacia do Piracicaba. Coletâneas do "Notícias PiraCena": a bacia do Rio Piracicaba (ed. by E.S.B. Ferraz, L.A. Martinelli and E.R.L. Victoria), pp. 67-73. C. N. Editoria, Piracicaba.

Barreto, G.R. \& Herrera, E.A. (1998) Foraging patterns of capybaras in a seasonally flooded savanna of Venezuela. Journal of Tropical Ecology, 14, 87-98.

Brasil (1967) Lei n 5.197 de 03 de janeiro de 1967. Dispõe sobre a proteção à fauna e dá outras providências. Diário Oficial da Uniáo, 05, jan. 1967, Brasília.

CONAMA (2002) Resolução CONAMA No 302 e 303, de 20 de março de 2002 (URL: http://www.mma.gov.br/port/ conama/)

Couto, H.T.Z., Vettorazzi, C.A., Ferraz, S.F.B. \& Pompermayer Neto, P. (2000) Airbone videography as a data source for the decision-making process in agriculture. Proceedings of the International Conference on Geospatial Information in Agriculture and Forestry, Vol. 2., pp. 459-462. ERIM International, Lake Buena Vista, FL.

Dean, W. (1977) Rio Claro: Um sistema brasileiro de grande lavoura 1820-1920. Paz e Terra, Rio de Janeiro.

Eisenberg, J.F., O’Connell, M.A. \& August, P.V. (1979) Density, productivity and distribution of mammals in two Venezuelan habitats. Vertebrate ecology in the northern Neotropics (ed. by J.F. Eisenberg), pp. 187-207. Smithsonian Institution, Washington, DC.
Ferraz, K.M.P.M.B., Lechevalier, M.A., Couto, H.T.Z. \& Verdade, L.M. (2003) Damage caused by capybara on a corn field. Scientia Agrícola, 60, 191-194.

Gabriel, K.R. (1971) The biplot graphic display of matrices with applications to principal component analysis. Biometrika, 58, 453-467.

González Jiménez, E. (1978) Digestive physiology and feeding of capybaras (Hydrochoerus hydrochaeris). Handbook series in nutrition and food (ed. by M. Rechcigl), pp. 163-177. CRC Press, Cleveland.

González Jiménez, E. (1995) El capibara (Hydrochoerus hydrochaerus). Estado actual de su producción. Estudio FAO Produccion y Sanidad Animal, no. 122. FAO, Roma.

Herrera, E.A. \& Macdonald, D.W. (1989) Resource utilization and territoriality in group-living capybaras (Hydrochoerus hydrochaeris). Journal of Animal Ecology, 58, 667-679.

Igreja, A.C.M., Campos, B.E.S. \& Bliska, F.M.M. (2001) Estudo dos impactos alocativos das pastagens na região Centro-Sul do Brasil. Agricultura em São Paulo, 48, 19-140.

Instituto Geográfico e Cartográfico do Estado de São Paulo (IGC) (1980) Carta de utilização da terra do Estado de São Paulo. Escala de 1:250.000. Folha de Campinas, Guaratinguetá e Santos, São Paulo.

Kronka, F.J.N. (1994) Inventário Florestal do Estado de São Paulo. Celulose e Papel, 11, 31-33.

Kronka, F.J.N., Nalon, M.A., Matsukama, C.K., Pavão, M., Kanashiro, M.M., Durigan, G., Ywane, M.S.S., Lima, L.M.P.R., Baitello, J.B., Guillaumon, J.R., Fukuda, J.C., Shida, C.N., Barbosa, O., Barradas, A.M.F., Borgo, S.C., Monteiro, C.H.B., Pontinha, A.S., Andrade, G.G., Joly, C.A. \& Couto, H.T.Z. (2003) Inventário florestal do estado de São Paulo. Instituto Florestal de São Paulo, São Paulo.

Krusche, A.V., Camargo, P.B., Cerri, C.E., Ballester, M.V., Victoria, R.L. \& Martinelli, L.A. (2003) Acid rain and nitrogen deposition in a sub-tropical watershed (Piracicaba): ecosystem consequences. Environmental Pollution, 121, 389399.

Labruna, M.B., Kerber, C.E., Ferreira, F., Faccini, J.L.H., De Waal, D.T. \& Cennari, S.M. (2001) Risk factors to infections and their occurrence on horses in the state of Sao Paulo, Brazil. Veterinary Parasitology, 97, 1-14.

Labruna, M.B., Whitworth, T., Horta, M.C., Bouyer, D.H., McBride, J.W., Pinter, A., Popov, V., Gennari, S. \& Walker, D.H. (2004) Rickettsia species infecting Amblyomma cooperi ticks from an area in the State of Sao Paulo, Brazil, where Brazilian spotted fever is endemic. Journal of Clinical Microbiology, 42, 90-98.

Lara, L.B.L.S., Artaxo, P., Martinelli, L.A., Victoria, R.L., Camargo, P.B., Krusche, A., Ayers, G.P., Ferraz, E.S.B. \& Ballester, M.V. (2001) Chemical composition of rain water and anthropogenic influences in the Piracicaba River basin, southeast Brazil. Atmospheric Environment, 35, 49374945.

Macdonald, D.W. (1981) Dwindling resources and the social behaviour of capybara (Hydrochoerus hydrochaeris) (Mammalia). Journal of Zoology of London, 194, 371-391. 
Martinelli, L.A., Ballester, M.V., Krusche, A.V., Victoria, R.L., Camargo, P.B., Bernardes, M. \& Ometto, J.P.H.B. (1999) Landcover changes and $\lambda^{13} \mathrm{C}$ composition of riverine particulate organic matter in the Piracicaba River Basin (Southeast region of Brazil). Limmonology and Oceanography, 44, 1826-1833.

McCullough, D.R. (1997) Irruptive behavior in ungulates. The science of overabundance: deer ecology and population management (ed. by W.J. Mcshea, H.B. Underwood and J.H. Rappole), pp. 69-98. Smithsonian Institution Press, Washington, DC.

McGarigal, R.H.G., Cushman, S. \& Stafford, S. (2000) Multivariate statistics for wildlife and ecology research. SpringerVerlag, New York.

Moreira, J.R. (2004) Avaliação do atual estado de uso e da conservação da capivara no Brasil. XLI Reunião Anual da Sociedade Brasileira de Zootecnia, pp. 517-527. Embrapa Gado de Corte, Campo Grande.

Moreira, J.R. \& Macdonald, D.W. (1997) Técnicas de manejo de capivaras e outros grandes roedores na Amazônia. Manejo e conservação de vida silvestre no Brasil (ed. by C. Valladares-Pádua, R.E. Bodmer and L. Cullen Jr), pp. 186-213. Sociedade Civil Mamirauá, Belém.

Moreira, J.R., Pinha, P.R.S. \& Cunha, H.J. (2001) Capivaras do Lago Paranoá. Olhares sobre o Lago Paranoá (ed. by F.O. Fonseca), pp. 141-147. Secretaria de Meio Ambiente e Recursos Hídricos, Brasília.

Ojasti, J. (1973) Estudio biologico del chigüire o capibara. Ed. Fondo Nacional de Investigaciones Agropecuarias, Caracas.

Ojasti, J. (1991) Human exploitation of capybara. Neotropical wildlife use and conservation (ed. by J.G. Robinson and K.H. Redford), pp. 236-252. The University of Chicago, Chicago.

Pereira, M.C. \& Labruna, M.B. (1998) Febre maculosa: aspectos clínico-epidemiológicos. Clínica Veterinária, 3, 1923.

Quintana, R.D. \& Rabinovich, J.E. (1993) Assessment of capybara (Hydrochoerus hydrochaeris) populations in the wetlands of Corrientes, Argentina. Wetlands Ecology and Management, 2, 223-230.

Quintana, R.D., Monge, S. \& Marvárez, A.I. (1994) Feeding habits of capybara (Hydrochaeris hydrochaeris) in afforestation areas of the Lower Delta of the Paraná River, Argentina. Mammalia, 58, 569-580.

Quintana, R.D., Monge, S. \& Marvárez, A.I. (1998) Feeding patterns of capybaras Hydrochaeris hydrochaeris (Rodentia, Hydrochaeridae) and cattle in the non-insular area of the Lower Delta of the Paraná River, Argentina. Mammalia, 62, $37-52$.

São Paulo (Estado) (1994) Estabelecimento de Metas ambientais e reenquadramento dos corpos d'água: bacia do Rio Piracicaba. Secretaria do Meio Ambiente, São Paulo.
São Paulo (Estado) (2001) Consórcio Intermunicipal das Bacias dos Rios Piracicaba, Capivari e Jundiaí. Capacitação de educadores em educação ambiental voltada à gestão os recursos hídricos. Fundo Estadual dos Recursos Hídricos, São Paulo.

São Paulo (Estado) (2005) Inventário da cobertura vegetal natural do estado de São Paulo. Secretaria do Meio Ambientel Instituto Florestal. Imprensa Oficial, São Paulo.

Sidle, J.G. \& Ziewitz, J.W. (1990) Use of aerial videography in wildlife habitat studies. Wildlife Society Bulletin, 18, 56-62.

Vicente, J.R., Anefalos, L.C. \& Caser, D.V. (2001) Produtividade agrícola no Brasil, 1970-1995. Agricultura em São Paulo, 48, 33-55.

Verdade, L.M. (2006) The influence of hunting pressure on the social behavior of vertebrates. Revista Brasileira de Biologia, $56,1-13$.

Verdade, L.M. \& Ferraz, K.M.P.M.B. (2006) Capybaras (Hydrochoerus hydrochaeris) in an anthropogenic habitat in Southeastern Brazil. Brazilian Journal of Biology, 66(1b), 371-378.

\section{BIOSKETCHES}

K.M.P.M.B. Ferraz is a post-doctoral researcher at the Forest Science Department of the University of São Paulo, Brazil. Her research focuses on vertebrate monitoring and management and on ecological niche modelling.

S.F.B. Ferraz is a post-doctoral researcher at the Rural Engineering Department of the University of São Paulo, Brazil. His research focuses on applications of GIS in conservation biology.

J.R. Moreira is a researcher at Embrapa (Brazilian Agricultural Research Institute). His work focuses on wildlife management and conservation and on ethnozoology.

H.T.Z. Couto is a full lecturer of Forest Inventory and Biostatistics at the Department of Forest Sciences of the University of São Paulo, Brazil. His research focuses on wildlife population surveys and forest inventory methodology, with emphasis on sampling techniques.

L.M. Verdade is an associate lecturer at the Department of Biological Sciences of the University of São Paulo, Brazil. His research focuses on vertebrate ecology and wildlife management.

Editor: Malte Ebach 